\title{
CORPORATE FINANCING IN GREAT BRITAIN
}

\author{
The Charterhouse Finance Corporation Limtted*
}

INTRODUCTION

In studying the methods by which British industry raises capital today it is essential to understand the sources from which the capital can be obtained, the methods whereby it is translated from the lender to the borrower, and the restrictions which are imposed by controls upon both lender and borrower. For the purpose of this article we are dealing with the financing of businesses constituted as public companies with limited liability.

The methods of financing war-time production had considerable influence on postwar financing and the capital markets. The major requirement in a capitalist economy is for risk-bearing capital which will carry the burdens or reap the rewards of free enterprise. Under the existing economy of Great Britain today, circumscribed as it is by controls and restrictions as well as heavy taxation, it is difficult to recognize the prewar concept of free enterprise but, outside the recently nationalized industries, its principles still remain and are those whereby industrialists still regulate their affairs.

$$
\text { I939-1945-Financing THE WAR }
$$

In establishing a war economy in 1939 it became necessary for the Government to direct the energies of industry primarily towards the maintenance of our navy, army, and air force in effective operation by keeping full supply lines. A system of controls and regulations for the supply of raw materials grew up and in their wake came the control of capital for the financing of the war machine, responsibility for which automatically devolved upon the Treasury.

The money required for this purpose and for nearly all the requirements of industry at this time was obtained by direct and indirect taxation in the form of income tax, profit taxes, company excess profits taxes, national defence contributions, purchase tax; and also from savings which the public placed in Government securities of all kinds. Government issues were made primarily to provide the necessary finance for war purposes, but the savings campaign also had as its objective the removal of surplus spending power from the people so as to avoid inflation.

During this period industry was, broadly speaking, being financed by British Government securities carrying a low rate of interest. The sources from which these funds were subscribed were the savings in the hands of the public, surplus funds available in the banks and industrial companies, and also the income of life assurance companies. The latter had; indeed, early in the war, voluntarily agreed to support

\footnotetext{
- The Charterhouse Finance Corporation Limited is a leading issuing house in the City of London and is a wholly owned subsidiary of The Charterhouse Investment Trust Limited of London.
} 
Government War Loans with the whole of the increase in their home funds, which were augmented by the sterling proceeds from requisitioning of overseas investments which were sold to provide the foreign currency required to finance purchases of war materials abroad.

The effect of these measures was to canalize the funds of individuals and institutions, who normally provide industry with its working capital, into Government securities. The amount of the national debt had therefore risen out of all peace-time proportions in relation to the capital normally invested in industry.

\section{Reconversion to Peace}

The process of converting industry to peace-time requirements from those of war was a problem of first-class magnitude, both physically and financially. Industry needed to re-tool and re-equip itself, to re-design its many peace-time products, to re-establish old markets, and to seek new. Men from the services had to be absorbed, re-trained in their old jobs or-for the newcomer-trained afresh. These problems occupied the country through the later months of 1945 , the whole of 1946 , and in many cases part of 1947. Where were the materials and money for this job?

The materials were available, although in many cases in short supply, but the adaptation of war-time plant was not always immediately practicable. It was during this period, and for the reason that Great Britain, in common with the whole of Europe, was through force of circumstances non-productive, that the United States generously made money and materials available under the Marshall Plan to help feed and sustain us.

The problem of financing this reconstruction period was difficult. There were fortunate companies whose peace-time production had been equally applicable to the needs of war and therefore they had no reconversion problem; others whose peace-time activities had ceased at the outbreak of war had major problems. An example of this is a catering and restaurant group which switched over from filling Swiss rolls and buns with cream to filling shells with explosive. The products were different but the principle of an efficient production line remained the same; nevertheless, their post-war problems were severe.

We have seen that the monetary picture had been distorted owing to the incidence of taxation-in particular the operation of the excess profits tax, which as its name implies effectively siphoned off profits made over and above a pre-determined standard. Few businesses during the war were able to retain profits to assist reconstruction Of course many old established businesses maintained a healthy financial position throughout and did not need help if their reconstruction problem was slight, but many who had major reconversion problems did need help. Again many had had their factories damaged by bombing, if not totally destroyed, and their machinery wrecked.

Initially the problem was solved by bank borrowing. Factories which had been 
built by the Government during the war were sold on advantageous terms to many of the companies occupying them, and by many such means the Government helped industry to get on its feet. Inevitably, however, during the period since the war inflation had taken place and it became essential for many businesses eventually to convert borrowings and indebtedness into permanent capital in order to avoid straining bank credit and, at the same time, maintain a satisfactory volume of trade.

\section{The Caprtal Market}

It is pertinent here to consider the capital market whose services provide the British capitalist with the finance he requires for his business. The capital market has been developed by private enterprise and consequently is extremely sensitive and adaptable. Its foundation is the issuing house, a financial institution which, on the one hand, keeps itself acquainted with the needs of industry for capital, and, on the other, with the views and inclinations of investors generally. The industrialist becomes dependent upon the specialized experience and services of the issuing house when the time comes to fund borrowings or otherwise to raise new permanent capital.

In the postwar period the requirements of industry were many and varied and the major responsibility of this section of the capital market was, by the most careful investigation, to satisfy itself that it found capital only for those companies whose projected or existing peace-time production was essential to the community, whose businesses were honestly run on sound commercial lines with good management, and who could put to profitable use the capital they were raising.

In all cases, consideration must be given not only to the circumstances peculiar to the company under review, such as the existing capital structure, but also to the general market conditions at the time and the opinions and sentiment prevailing amongst investors. The market for new issues fluctuates; at times ordinary shares are popular and at other times preference or loan capital is more easily absorbed. On occasion certain industries fall under a cloud so that investors will not buy shares in companies engaged in them.

Total Company Issues

"Economist" New Basis eXpressed as percentages

\begin{tabular}{|c|c|c|c|c|c|c|c|c|}
\hline Type of Issue & 1938 & 1939 & 1945 & 1946 & 1947 & 1948 & 1949 & 1950 \\
\hline $\begin{array}{l}\text { Debenture } \% \ldots \ldots \ldots \ldots \\
\text { Preference } \% \ldots \ldots \ldots \ldots\end{array}$ & $\begin{array}{l}21.16 \\
13.65\end{array}$ & $\begin{array}{l}23.00 \\
11.97\end{array}$ & $\begin{array}{l}5.04 \\
9.42\end{array}$ & $\begin{array}{r}6.71 \\
16.04\end{array}$ & $\begin{array}{l}11.49 \\
19.68\end{array}$ & $\begin{array}{r}6.13 \\
19.20\end{array}$ & $\begin{array}{r}8.95 \\
26.80\end{array}$ & $\begin{array}{l}37.51 \\
10.19\end{array}$ \\
\hline $\begin{array}{r}\text { Total fixed-interest- } \\
\text { bearing stocks \% } \% \\
\text { Ordinary } \% \text {. . . . }\end{array}$ & $\begin{array}{l}34.81 \\
65.19\end{array}$ & $\begin{array}{l}34.97 \\
65.03\end{array}$ & $\begin{array}{l}14.46 \\
85.54\end{array}$ & $\begin{array}{l}22.75 \\
77.25\end{array}$ & $\begin{array}{l}31.17 \\
68.83\end{array}$ & $\begin{array}{l}25.33 \\
74.67\end{array}$ & $\begin{array}{l}35.75 \\
64.25\end{array}$ & $\begin{array}{l}47.70 \\
52.30\end{array}$ \\
\hline$\%$ & 100.00 & 100.00 & 100.00 & 100.00 & 100.00 & 100.00 & 100.00 & 100.00 \\
\hline Totals $£$ million... & 159.7 & 73.5 & 107.2 & 271.2 & 295.8 & 236.5 & 178.7 & 193.3 \\
\hline
\end{tabular}


It is interesting to insert here figures prepared by the London Economist on the amount of money raised in $193^{8}$ and 1939 and for the years 1945 to 1950 inclusive, showing the breakdown of the types of security issued. The figures are shown as percentages and are divided into debentures which include dated loan stock; preference shares or preferred shares; and ordinary shares which are the equivalent of the common stock in an American company.

The first point of interest to note is that in general the bulk of the capital requirement of industry was applied in the form of "risk" capital, or ordinary shares as we know them, and that the year in which the highest percentage of that type of capital was provided was 1945 , the first year of reconstruction. It evidences the willingness of the investor or lender to take the risks necessary to refinance industry at that time. In the succeeding years of 1946 and 1947 the highest total sums were raised amounting to 271.2 and 295.8 million pounds respectively, and we see a gradual reduction of the percentage raised in ordinary shares, and an increasing preponderance going into the preference (or preferred) shares, and, to a lesser extent, debentures or loan stock.

In 1948 and 1949 we see the growing popularity of the preference shares, which showed the tendency of the investor or lender in those years to demand greater security for his money. This was further accentuated in $195^{\circ}$ when he was tempted to buy only the better or best types of preference shares, and in many cases, as a condition of his investment in industry, began to demand a charge on the assets in the form of debentures. The wheel has indeed almost turned a full cycle from the days of 1945 when it was possible to raise considerable sums in the equity of businesses on only postwar and wartime records, to the situation we are facing today in which the fullest possible security is required by lenders and only first-class industrial concerns can raise equity capital, or common stock, on reasonable terms.

This movement has inevitably caused interest and dividend rates to rise and as a consequence we have seen a tendency among institutions to divest themselves of a proportion of relatively low-interest-bearing Government securities and to purchase in their place any available first-class industrial debentures which carry a higher and more attractive interest rate.

\section{INTEREST RATES}

The bulk of the finance required by British industry is obtained in the form of stocks or shares which become quoted on the London Stock Exchange or provincial stock exchanges, and it is, therefore, possible to follow the trend of interest rates. Stock markets generally are moved by three forces: (a) politics, (b) economics, and (c) sentiment or the attitude of the investor to politics and economics and any other factor he considers relevant.

Interest rates are determined by the effect these three factors have on markets and it is interesting to see the trend over the past few years of certain typical classes of stocks as shown by the yields obtained on certain groups of stocks and shares. 
Corporate Financing in Great Britain,

\begin{tabular}{|c|c|c|c|c|c|c|c|c|}
\hline British Govt. Long-dat & $d^{193^{8}}$ & I939 & I945 & 1946 & I947 & 1948 & I949 & I950 \\
\hline $\begin{array}{l}\text { and Irredeemables } \\
\text { Selected Industrials }\end{array}$ & 3.53 & 3.78 & $2.9 \mathrm{I}$ & 2.60 & 2.87 & 3.24 & $3 \cdot 37$ & 3.57 \\
\hline $\begin{array}{l}\text { Debentures } \\
\text { Industrial Preference }\end{array}$ & 4.27 & 4.62 & 3.86 & 3.78 & 3.88 & 3.89 & 3.99 & 4.06 \\
\hline $\begin{array}{l}\text { Shares } \\
\text { Industrial Ordinary }\end{array}$ & 4.56 & 4.84 & $4.2 I$ & 4.09 & 4.10 & $4 \cdot I_{3}$ & 4.67 & $4.9 \mathrm{I}$ \\
\hline Shares & 6.28 & $6.6 \mathrm{I}$ & 4.55 & 4.66 & 4.80 & 5.03 & $5.5^{0}$ & $5 \cdot 37$ \\
\hline
\end{tabular}

Certain facts emerge from these figures. The first is the comparative effectiveness of the Government's methods of controlling the "gilt-edged" market so as to continue borrowing and carry out refunding operations at the cheapest rate possible. In large measure this object has been achieved over the past five years, as it will be seen that during the postwar period the yield on British Government long-dated stocks did not rise above the figure for $193^{8}$ until 1950 . The fall in the price of Government stocks has continued during $\mathrm{x} 95 \mathrm{I}$ and yields have consequently increased beyond the figure shown for 1950 .

The second fact is that the industrialist took advantage of the ruling cheap money period, and by offering rates which appeared tempting in comparison with Government securities frequently got the backing he required. Over the past twelve months however money has become more difficult to obtain and as a consequence industry has had to offer comparatively attractive terms for loans.

During $195^{\circ}$ and early $195^{1}$ a number of companies which are industrial leaders in Britain raised considerable sums by means of short and medium term loans, some of which were placed privately without a stock exchange quotation, and some of which were issued through the normal machinery of the capital market.

A list of these is given below:

The amount raised in this type of security during 1950 represented a considerable part of the total capital issues made by corporate bodies. It is important to note that of the eleven issues mentioned above only six were made with a stock exchange quotation. The remaining five totalling 32 million pounds were placed privately, chiefly in large blocks with insurance companies.

The capital market was particularly open to attractive first-class securities of the type mentioned above as most insurance companies had funds to invest and very little stock was available in the market. These issues drew off a very considerable proportion of the surplus investment cash available, with the result that Government stocks became relatively unattractive. The funding operation to convert the residue of 209 million pounds of $1949-5 \mathrm{I}$ National War Bonds into new 3 per cent Funding Stock Ig66-68 was below expectations, and the following paragraph by the City Editor of The Times was published on November 14, $1950:^{1}$

\footnotetext{
${ }^{1}$ P. 8, col. I (Italics supplied).
} 
Short Term LoANS

\begin{tabular}{|c|c|c|c|c|}
\hline Company & $\begin{array}{l}\text { Amount } \\
\text { Raised }\end{array}$ & $\begin{array}{c}1950 \\
\text { Type of Security }\end{array}$ & $\begin{array}{l}\text { Length of } \\
\text { Life }\end{array}$ & Market \\
\hline The British Oxygen Co. Itd.. & $£ 4,000,000$ & $33 / 4 \%$ Unsecured Loan & 3- 5 years & Placed \\
\hline Cadbury Bros. Ltd.. & $£ 3,000,000$ & $4 \%$ Unsecured Notes & $8-13$ years & Placed \\
\hline The Distillers Co. Ltd.... & $£ 4,000,000$ & $\begin{array}{l}31 / 2 \% \text { Unsecured Loan } \\
\text { Stock }\end{array}$ & 2- 5 years & $\begin{array}{l}\text { Placed } \\
\text { privately. }\end{array}$ \\
\hline $\begin{array}{l}\text { Goodyear Tyre \& Rubber } \\
\text { Co. Ltd................ }\end{array}$ & $£ 1,500,000$ & $\begin{array}{l}\text { 4\% Redeemsble } \\
\text { Debenture Stock }\end{array}$ & 5-20 years & $\begin{array}{l}\text { Stock exchange } \\
\text { quotation. }\end{array}$ \\
\hline $\begin{array}{l}\text { Imperial Chemical Industries } \\
\text { Limited............... }\end{array}$ & $£ 20,000,000$ & $\begin{array}{l}\text { 4\% Unsecured Loan } \\
\text { Stock }\end{array}$ & $8-10$ years & $\begin{array}{l}\text { Placed } \\
\text { privatoly. }\end{array}$ \\
\hline $\begin{array}{l}\text { Imperial Tobacco Co. } \\
\text { (of Great Britain and } \\
\text { Ireland) Ltd............. }\end{array}$ & $£ 20,000,000$ & $4 \%$ Unsecured Losn & $10-20$ years & Stock exchange \\
\hline Lewis Berger \& Sons Itd. & $£ 1,000,000$ & $\begin{array}{l}4 \% \text { Unsecured Loan } \\
\text { Stock }\end{array}$ & $5-10$ years & $\begin{array}{l}\text { Stock exchange } \\
\text { quotation. }\end{array}$ \\
\hline 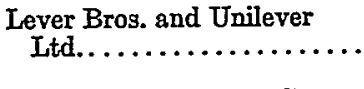 & $£ 10,000,000$ & $\begin{array}{l}33 \% \% \text { Redeemable } \\
\text { Debenture Stock }\end{array}$ & $5-25$ years & $\begin{array}{l}\text { Stock exchange } \\
\text { quotation. }\end{array}$ \\
\hline $\begin{array}{l}\text { The Morgan Crucible Co. } \\
\text { Itd.................. }\end{array}$ & $£ 1,000,000$ & $\begin{array}{l}4 \% \text { Guaranteed Loan } \\
\text { Stock }\end{array}$ & $5-10$ years & $\begin{array}{l}\text { Placed } \\
\text { privately. }\end{array}$ \\
\hline Gallaher Ltd. & $£ 2,000,000$ & $\begin{array}{l}1951 \\
4 \% \text { Unsecured Loan } \\
\text { Stock }\end{array}$ & $9-14$ years & $\begin{array}{l}\text { Stock exchango } \\
\text { quotation. }\end{array}$ \\
\hline Godfrey Phillips Ltd.. & $£ 2,000,000$ & $\begin{array}{l}\text { 41/4\% Unsecured Loan } \\
\text { Stock }\end{array}$ & $10-15$ years & $\begin{array}{l}\text { Stock exchango } \\
\text { quotation. }\end{array}$ \\
\hline
\end{tabular}

\section{THE CONVERSION RESULT}

The residue of $£ 209 \mathrm{~m}$. of $1949-5 \mathrm{r}$ National War Bonds has been reduced to some firim. by the offer to holders to convert into the new 3 per Cent. Funding Stock 1966 68. The Treasury announced last evening that approximately $£ 88 \mathrm{~m}$. of the War Bonds had been tendered for conversion. This figure excludes bonds on the Post Office Register, but as these must be very small any further conversions will not affect the result materially.

In one respect the figure of $£ 88 \mathrm{~m}$. is well below expectations. It was believed beforehand that $£$ I $50 \mathrm{~m}$. or so of the maturing bonds were already held by the public departments, who would presumably convert into the new stock. The actual total tendered for conversion suggests either that the departments have chosen in fact to retain a substantial proportion of their holdings for redemption on February $I$ or that they had already disposed of most of them before the latest offer. On the whole this last seems to be the more likely explanation. The departments had an earlier opportunity, in June, of converting into $2 \frac{1}{2}$ per Cent. Funding Loan, 1956-6x, and there have been other opportunities doubtless in the rising market for the Funds since then of peddling out stock to ordinary buyers.

If this is true, however, then the buyers must have been the large corporate and institutional investors, for the money market is not thought to hold any quantity of the maturing bonds; and the present conversion result means that these corporate investors do not want a 3 per cent. 16-18-year Government stock. They may well feel that there may be moret 
profitable opportunities for employing the redemption moneys next year in taking up more short-term industrial note issues.

\section{The Investor}

The chief supporters of the capital market today are the insurance companies, pension funds, the investment trusts, and, to a limited extent, the merchant banking houses and private investors. The two last named are not important factors. The merchant banks during a period of inflation and active trade are usually fully extended in financing trade. The private investor, owing to the incidence of high taxation, has to a large extent ceased to have surplus funds available year by year out of income and is left with his permanent capital-if any-which in most cases he is reluctant to venture outside safe securities.

We are left, therefore, with the investment trusts, insurance companies, and pension funds. Investment trusts are currently precluded-by government regulation -from raising large sums of fresh capital, but they may, if they so wish, raise a sum of not more than $£_{50,000}$ annually in any one company. Very few have taken advantage of this concession and their market activities are therefore confined to switching operations and the investment of normal surplus income.

The only investors with new funds continually available for investment are therefore the insurance companies and pension funds. The savings of the man in the street are now, to a great extent, channelled into the insurance companies in the form of life or endowment insurance, educational policies, house mortgages, and many other types of policies. Subscriptions to pension funds in many cases become almost a condition of employment. The attraction to the public of these forms of savings lies in the fact that a substantial measure of relief from the personal income tax is allowed on premiums and pension contributions, and thereby such policies contain an element of additional saving beyond the normal premiums payable.

\section{INSURANCE COMPANIES}

From the preceding paragraph it will be appreciated that the major continuing source of fresh funds for the capital market comes from the life assurance companies, and the following table shows the net income which was available from this source in the years 1945 -r 949 .

The investment policy of the insurance companies, as a whole, is dictated by their need to provide life cover rather than profits, and maintenance of capital values is therefore of paramount importance. The rise or fall in price of a security which is to

Net Income of Life Assurance Companies in United Kingdom (Ordinary and Industrial Business)

$$
\text { f. thousands }
$$

\begin{tabular}{|c|c|c|c|}
\hline $\begin{array}{c}1945 \\
£ 92,348\end{array}$ & $\begin{array}{c}1946 \\
f_{\text {III }, 613}\end{array}$ & $\begin{array}{c}1947 \\
£=12,844\end{array}$ & $\begin{array}{c}{ }^{194^{8}} \\
f^{123,5}{ }^{14}\end{array}$ \\
\hline
\end{tabular}

(Figures obtained from The Annual Abstract of Statistics, published by The Central Statistical Office, and advance information received from The Statistics Division of The Board of Trade). 
be held to maturity is not of major importance except to the extent that current market prices are used to value stocks in the annual balance sheets.

As explained previously the insurance companies during the war had agreed to utilize the whole of their home premium income in the support of Government issues, and as a result, at the end of the war, the amount invested in this type of security had increased considerably over prewar totals.

This fact should be borne in mind, and also that post-war investment policy has largely been dictated by government action or decree. Soon after the war the Socialist Government then in power defined its investment policy and issued instructions to the Treasury, which were transmitted to the banks, for the control of credit. It set up a Capital Issues Committee which operates with the Treasury in controlling not only the amount of capital raised through the capital market but also the direction in which funds so raised are used. A company requiring fresh capital must submit proof to this Committee, by reference to the various ministries or national boards within whose sphere it operates, that its activities are of national importance and its requirements reasonable and well founded.

The Government's cheap money policy, as we have seen, also had a considerable effect on markets and consequently on investment policy. British insurance companies are not required by law to utilize a fixed proportion of their funds in Government securities, but prudence requires that they should do so, and, as a result, a very considerable percentage is always invested in what are termed "gilt-edged" securities. A further high percentage is in British municipal and corporation stocks, colonial government stocks, and loans on mortgages, policies and rates.

We are indebted to The Prudential Assurance Company Limited of London for permission to use a table compiled by them summarizing the distribution of assets of twelve large British insurance companies. The figures include general as well as life fund assets:

For reasons already discussed the proportion of British Government securities increased during the war from $26.5^{6}$ per cent in $193^{8}$ to 39.08 per cent in I943 but it is also interesting to note that during the years to 1949 this figure had again increased to 43.5I per cent.

Loans on mortgages, policies, rates, and other securities, excluding stocks and shares, declined from I2.22 per cent in I938 to 6.32 per cent in I949. Municipal and county stocks declined from 4.I4 per cent to r.64 per cent; stocks and shares remained almost stationary, the respective figures being r938-r6.57 per cent, and r949-r6.86 per cent, although the sum invested increased from approximately 149 million pounds, to 243 million pounds. The only other major change was in the item "Miscellaneous" which rose from 5.74 per cent to 7.55 per cent, or 5 I million pounds to rog million pounds. Debentures declined slightly in value from $149 \frac{1}{2}$ million pounds to 147 million pounds, but their percentage of the total invested funds dropped from $16.6 \mathrm{r}$ per cent to I0.19 per cent. In considering these figures we must 
Distribution of Assets

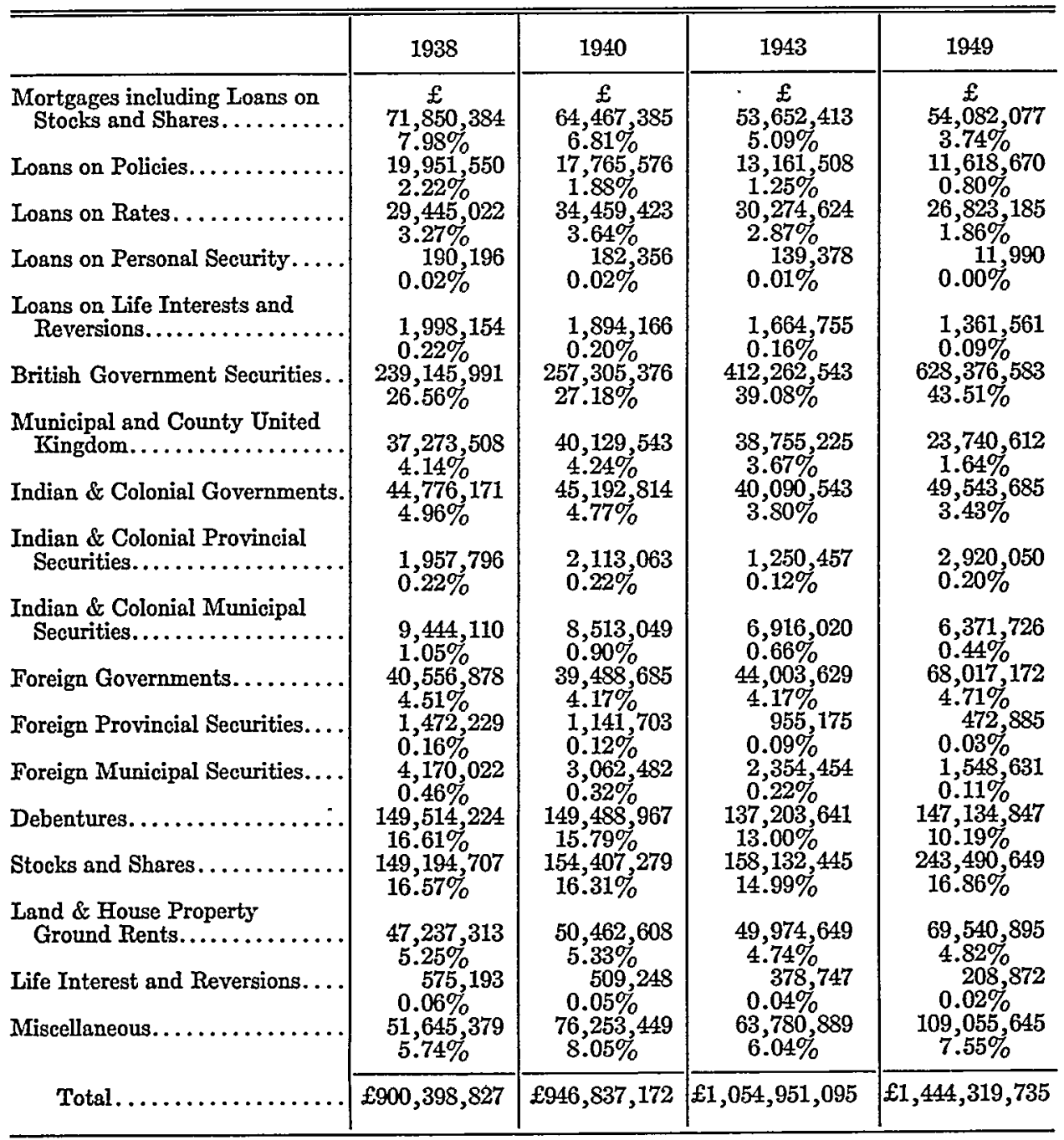

Note: The percentage figures represent the proportion of total assets.

bear in mind that the total funds invested increased from 900,398,827 pounds in I938 to $1,444,319,735$ pounds in 1949 , an increase of some 543 million pounds or over 60 per cent. The increase of British Government securities from 239,145,99r pounds ( $26.5^{6}$ per cent) in $193^{8}$ to $628,376,5^{8} 3$ pounds ( $43.5^{I}$ per cent) in I949 absorbed some $3^{89}$ million pounds, or over 70 per cent, of the available surplus. It would appear, therefore, that during this period these companies had invested a more than proportionate amount in this type of security.

It should not be assumed that insurance companies were less willing to invest in industry during the post-war years, but rather that they were unable to find a 
sufficiently high percentage of suitable industrial securities, and consequently turned to the "gilt-edged" market to invest surplus funds. The favorable reception accorded to the short-term issues of high quality in the latter half of 1950 , shows the readiness of insurance companies and other investors to absorb attractive industrial issues. Considerable investment demand arose also in the first quarter of $195 \mathrm{I}$ for first class ordinary shares as a hedge against continued inflation, but this movement became less evident towards the middle of the summer and by the autumn had virtually ceased.

\section{INVESTMENT TRUsts}

The investment trusts are not a considerable source of new funds for the market as they can only provide surplus income for this purpose.

A table showing the distribution of assets of twelve of the larger British investment trusts is given below, with the changes which have taken place since 1938 .

Investment Trusts-Distribution of Assets

\begin{tabular}{|c|c|c|c|c|c|c|c|}
\hline & 1938 & 1941 & 1943 & 1915 & 1947 & 1019 & 1050 \\
\hline \multirow[t]{2}{*}{$\begin{array}{l}\text { Bonds and Debentures.......... } \\
\text { Preference Stocks and Shares..... } \\
\text { Ordinary Stocks and Shares...... }\end{array}$} & $\begin{array}{l}26.66 \% \\
28.69 \% \\
44.65 \%\end{array} \mid$ & $\begin{array}{l}29.30 \% \\
26.07 \% \\
44.63 \%\end{array}$ & $\begin{array}{l}27.07 \% \\
28.53 \% \\
44.40 \%\end{array} \mid$ & $\begin{array}{l}26.51 \% \\
29.75 \% \\
43.74 \%\end{array}$ & $\begin{array}{l}21.30 \% \\
27.07 \% \\
51.63 \%\end{array}$ & $\begin{array}{l}16.14 \% \\
25.74 \% \\
58.12 \%\end{array}$ & $\begin{array}{l}14.87 \% \\
23.99 \% \\
61.14 \%\end{array}$ \\
\hline & 100.00 & 100.00 & 100.00 & 100.00 & 100.00 & 100.00 & 100.00 \\
\hline
\end{tabular}

The above table can give only a slight indication of the changes which have taken place in this group of representative companies. The figures are taken from the balance sheets of the various companies and in most cases the value put upon the stocks and shares is at cost price and not market value. As this basis has to be used the changes in the market value of portfolios is not apparent. The effect of price rises and falls in the three groups shown above is not therefore reflected in the figures until such time as sales of one class take place and funds are transferred to another.

Movements are however seen from I945 onwards when stock market activity increased and a general trend is shown. From $x 945$ to I950 bonds and debentures were reduced from $26.5 \mathrm{I}$ per cent to 14.87 per cent; preference shares reduced from 29.75 per cent to 23.99 per cent and, as a consequence, holdings of ordinary stocks and shares increased from 43.74 per cent to $6 \mathrm{r} .14$ per cent. The broad generalization, therefore, emerges that the investment trusts became less interested in fixed-interestbearing securities and more interested in ordinary shares-or the equity of industry. The holdings of these investment trusts included American and foreign securities.

Over the past two or three years certain of the important investment trust groups have been reverting to a pre-war practice of investing a percentage of their funds in United States and Canadian stocks. 
As American stocks have become available these groups have been buyers of them and consequently sellers of British stocks and shares. The devaluation of sterling produced considerable increases in book values (in sterling) of American holdings and many trusts purchased additional stocks and shares to average existing holdings. There is an added attraction for the British investor in holding American stocks in that by the operation of the Double Taxation Agreement between the two countries a relief from part of British income tax is obtained on income received from American stocks and shares, which has the effect of increasing the yields obtainable, in some cases to very attractive levels.

\section{INVESTMENT TRENDS}

As we have seen, there was a much greater disposition in 1945 and I946 to put up "risk" capital for business in the form of ordinary shares than in 1950. This has produced a very definite movement as in order to make successful issues and insure that the required capital is forthcoming, companies concerned are compelled by the requirements of the investor to make offers of shares to their shareholders on attractive terms well below the market prices ruling.

This applies even to the leading industrial concerns and the following are some examples:

The urgent needs of industry for capital, in some cases required to finance the purchase of raw materials which have risen steeply in price in the past two years, could often only be met by the issue of prior charges-debentures or loan stock or preference shares. The accompanying table which compares the capital structure in I94I and I950 of eight British and eight American companies engaged in the same industries illustrates the trend.

Issues to Shareholders on Bonus Terms

\begin{tabular}{|c|c|c|c|c|c|}
\hline Company & $\begin{array}{c}\text { Cash raised } \\
\text { by Ordinary } \\
\text { Issues }\end{array}$ & $\begin{array}{l}\text { Date of } \\
\text { Issue }\end{array}$ & $\begin{array}{l}\text { Price at } \\
\text { which } \\
\text { Offered to } \\
\text { Shareholders }\end{array}$ & Ratio & $\begin{array}{l}\text { Market } \\
\text { Price } \\
\text { at Time } \\
\text { of Issue }\end{array}$ \\
\hline \multicolumn{6}{|c|}{1950} \\
\hline 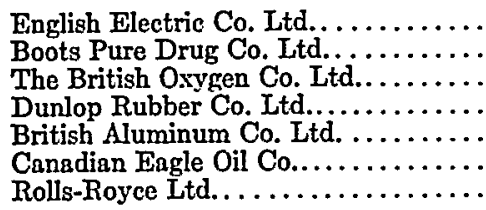 & $\begin{array}{l}£ 1,032,130 \\
£ 2,240,000 \\
£ 2,428,370 \\
£ 8,941,890 \\
£ 3,400,000 \\
£ 4,998,470 \\
£ 1,437,500\end{array}$ & $\begin{array}{l}\text { January } \\
\text { March } \\
\text { November } \\
\text { November } \\
\text { November } \\
\text { November } \\
\text { December }\end{array}$ & $\begin{array}{l}35 /- \\
35 /- \\
70 /- \\
40 /- \\
34 /- \\
22 /- \\
75 /-\end{array}$ & $\begin{array}{l}1 \text { for } 6 \\
1 \text { for } 5 \\
1 \text { for } 5 \\
2 \text { for } 5 \\
2 \text { for } 3 \\
7 \text { for } 30 \\
1 \text { for } 3\end{array}$ & $\begin{array}{l}42 / 6 \mathrm{~d} . \\
48 /- \\
90 /- \\
64 /- \\
42 / 6 \mathrm{~d} . \\
27 / 6 \mathrm{~d} . \\
113 / 9 \mathrm{~d} .\end{array}$ \\
\hline \multicolumn{6}{|c|}{1951} \\
\hline 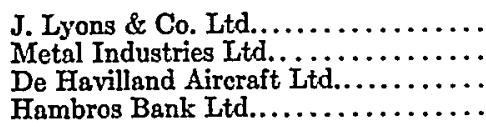 & $\begin{array}{l}£ 2,970,000 \\
£ 1,013,330 \\
£ 1,644,547 \\
£ 2,250,000\end{array}$ & $\begin{array}{l}\text { January } \\
\text { Mareh } \\
\text { June } \\
\text { June }\end{array}$ & $\begin{array}{l}90 /- \\
32 / 6 \mathrm{~d} \\
20 /- \\
45 /-\end{array}$ & $\begin{array}{l}1 \text { for } 3 \\
1 \text { for } 4 \\
9 \text { for } 10 \\
5 \text { for } 2\end{array}$ & $\begin{array}{l}101 / 3 \mathrm{~d} . \\
42 /- \\
27 / 9 \mathrm{~d} \\
65 / 9 \mathrm{~d}\end{array}$ \\
\hline
\end{tabular}




\begin{tabular}{|c|c|c|c|c|c|c|c|c|}
\hline \multirow[t]{2}{*}{ Companies } & \multicolumn{2}{|c|}{$\begin{array}{c}\text { (1) } \\
\text { Debentures } \\
\text { expressed as } \\
\text { \% of total } \\
\text { Capital }\end{array}$} & \multicolumn{2}{|c|}{$\begin{array}{l}(2) \\
\text { Preference or } \\
\text { Preferred } \\
\text { Capital } \\
\text { expressed as } \\
\% \text { of total } \\
\text { Capital }\end{array}$} & \multicolumn{2}{|c|}{$\begin{array}{l}\text { (3) } \\
\text { Total Prior } \\
\text { Charges } \\
\text { expressed as } \\
\text { \% of total } \\
\text { Capital }\end{array}$} & \multicolumn{2}{|c|}{$\begin{array}{c}(4) \\
\text { Ordinary } \\
\text { Capital } \\
\text { expressed as } \\
\text { \% of total } \\
\text { Capital }\end{array}$} \\
\hline & 1941 & 1950 & 1941 & 1950 & 1941 & 1950 & 1941 & 1950 \\
\hline 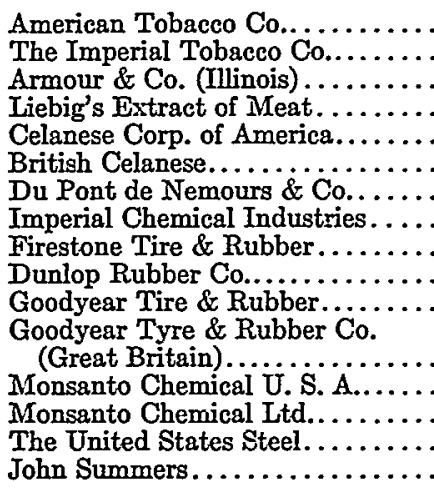 & $\begin{array}{c}9.13 \\
\ldots \ldots \\
\ldots \ldots \\
\ldots 3.5 \\
43.55 \\
23.73 \\
\ldots \ldots \\
\ddot{40.98} \\
19.93 \\
36.36\end{array}$ & $\begin{array}{l}54.43 \\
44.23 \\
65.85 \\
\ldots 3.06 \\
30.94 \\
19.11 \\
48.29 \\
30.89 \\
59.37 \\
42.85 \\
35.55 \\
\dddot{5} .09 \\
34.09\end{array}$ & $\begin{array}{l}28.86 \\
25.50 \\
73.60 \\
33.33 \\
54.52 \\
57.46 \\
43.28 \\
32.08 \\
41.69 \\
27.67 \\
54.34 \\
33.33 \\
58.49 \\
57.14 \\
29.91 \\
\ldots . .\end{array}$ & $\begin{array}{l}12.67 \\
14.22 \\
24.28 \\
50.00 \\
66.24 \\
53.73 \\
54.54 \\
23.01 \\
10.75 \\
23.79 \\
33.81 \\
34.29 \\
39.11 \\
62.50 \\
27.79 \\
20.72\end{array}$ & $\begin{array}{l}37.99 \\
25.50 \\
73.60 \\
33.33 \\
98.07 \\
81.19 \\
43.28 \\
32.08 \\
82.67 \\
47.60 \\
90.70 \\
33.33 \\
58.49 \\
57.14 \\
45.82 \\
\ldots \ldots\end{array}$ & $\begin{array}{l}67.10 \\
58.45 \\
90.13 \\
50.00 \\
98.30 \\
84.67 \\
54.54 \\
42.12 \\
59.04 \\
54.68 \\
93.18 \\
77.14 \\
74.66 \\
62.50 \\
32.88 \\
55.25\end{array}$ & $\begin{array}{r}62.01 \\
74.50 \\
26.40 \\
66.67 \\
1.93 \\
18.81 \\
56.72 \\
67.92 \\
17.33 \\
52.40 \\
9.30 \\
66.67 \\
41.51 \\
42.86 \\
54.18 \\
100.00\end{array}$ & $\begin{array}{r}32.90 \\
41.55 \\
9.87 \\
50.00 \\
1.70 \\
15.33 \\
45.46 \\
57.88 \\
40.96 \\
45.32 \\
6.82 \\
22.86 \\
25.34 \\
37.50 \\
67.12 \\
44.75\end{array}$ \\
\hline
\end{tabular}

(Compiled from Moodys' Services).

With the exception of two American companies-Firestone Tire and Rubber and United States Steel-the equity or common stock percentages of capital decreased, and with the exception again of those two companies the proportion of the total capital in prior charges was increased between those years.

It would appear from all figures which have been quoted that there has been a definite trend in the new issue market up to r950 towards security and away from equities, except in first-class businesses. This has tended to produce top-heavy capital structures in which prior charges predominate. The movement appears to have gone further in America than in the United Kingdom and appears to be inevitable during a period of combined political unrest and inflation which causes industry to require increasing loan facilities and credit to maintain trading turnover.

\section{Types of Security}

In the postwar period the types of security offered on the capital market varied from the straight debenture stock, preference and ordinary share to short-term convertible loan notes and redeemable participating preference shares. Unorthodox types of security are a product and symptom of the times. British companies in addition to paying income tax on their profits and also a ro per cent profits tax, must pay a further tax on all distributed dividends which at present is at the rate of 40 per cent of the sum distributed. The io per cent profits tax and 40 per cent distribution tax can become extremely onerous for a company financed with a preponderance of preference or preferred capital carrying a high fixed dividend or coupon rate. De- 
bentures, notes, and loan stock do not attract the 40 per cent distribution tax and, therefore, are more attractive to borrowers. As a generalization therefore companies prefer to raise capital by means of debentures, loan stock or unsecured notes, instead of by preference, preferred or ordinary shares which attract this distribution tax, provided always that the capital structure is not thrown out thereby or bank credit affected.

To increase the attraction of preference shares it has sometimes been necessary to introduce a feature of redemption, or convertibility into ordinary shares. Insurance companies like to have redemption features in small companies so that they can envisage the ultimate liquidation of their holding. Such shares often impose an obligation on the company to apply, year by year, a certain proportion of its profit to provide a sinking fund or to carry out redemption by annual drawings. The cost of such sinking fund or drawings is not allowed as an expense of the company for taxation purposes and must bear tax at the current rates before being deducted from the trading profits for the year. There is a further obligation that if the sinking fund does not provide for the total extinction of the issue within the term of its life, then provision must be made on the final redemption date for the replacement or repayment of that portion which has not been redeemed meantime.

During the past two years considerable amounts of capital have been raised by means of short-term unsecured loan notes carrying attractive rates of interest. These have been mostly issued by companies requiring temporary finance in addition to their normal banking facilities to cover the increased cost of raw materials.

Holders of these notes rank as ordinary creditors of a company and in most cases the bank ranks before them. In other words, the holder of such a security becomes an ordinary trade creditor of the business and if liquidation occurs receives only the same treatment as a trade creditor, but is paid out in priority to preference or ordinary shareholders.

In some cases notes have carried a provision for conversion into ordinary shares at certain specified dates during the term of the life of the notes.

\section{ConcLusion}

There are one or two points of interest in the attitude and practice of the institutional investor which influence the methods of raising money for financing businesses. Insurance companies and investment trusts avoid acquiring majority holdings in any concern and do not seek to purchase the entire equity of any business. A majority or total equity holding in a business makes it a subsidiary and might impose the obligation of managing, or supervising the management, of such a business. Insurance companies and investment trusts are not in a position to provide technical or industrial management and can only provide, if required, financial direction. In certain cases therefore syndicates are formed to finance companies, or acquire large lines of share capital therein. Such syndicates are formed, not infre- 
quently, of insurance companies, investment trusts, merchant bankers, and others having funds to invest. Latterly, former coal and iron and steel companies, who have acquired cash as a result of the nationalization of their industries, have been making investments by this method.

Investment trusts, insurance companies, and other institutional investors are quite willing to invest in shares which have no quotation on any stock exchange provided that a sufficiently generous yield is obtainable to compensate for lack of marketability.

From the above necessarily brief study of the methods of financing British industry since the war it can be appreciated that nearly every known method of raising money has been used. Throughout I95I, the capital market has operated cautiously and on conservative lines, but there is ample evidence that British institutional investors will continuously seek to acquire equity holdings of proved merit and value and in every way assist in the development of British industry. 